\title{
ECOLOGY OF PREHISTORIC ALEUTIAN VILLAGE SITES ${ }^{1}$
}

\author{
THEODORE P. BANK, II \\ Botanical Gardens, University of Michigan, Ann Arbor, Michigan
}

Prehistoric Aleutian village sites are unique in that they possess characteristic vegetational and topographical configurations which set them distinctly apart from other habitats. Their features are easily distinguished from the surrounding landscape even at a great distance. This peculiarity led William Dall (1877), Jochelson (1925: 21-23), and Hrdlička (1937) to suggest the possibility that differences in vegetation might indicate the relative age of such sites.

This idea is, of course, not new to archaeology, nor is the application confined to the Aleutians, for vegetational patterns have been utilized as indicators of previous human activity by an increasing number of workers in recent years, especially in Europe, where there has perhaps been more awareness of human ecology. Worsaar studied succession of vegetational types in Danish peat profiles and discussed the possibilities of viewing prehistoric cultures against a background of evolving floras (Daniel 1950:303), and an impressive number of Europeans have used surface vegetational patterns as observed from the air during archaeological reconnaissance. Sir C. Fox and O. G. S. Crawford were among those to develop the technique in England where it has been widely used. In America a few archaeological surveys have included an inventory and interpretation of plant cover, e.g., H. M. Zeiner has shown that vegetation on the Angel Mound (Zeiner 1945) could indicate the exact area of primitive occupation quite independently of archaeological excavation. Kroeber (1947: 206) has discussed culture in relation to environment, writing, "Plant cover is obviously almost always likely to stand in

\footnotetext{
1 Paper from the Department of Botany and the Botanical Gardens, University of Michigan, No. 968.
}

relation to culture. It largely expresses climate; it tends heavily to determine the fauna; and it enters directly into subsistence, besides at times affecting travel and transport. It is rather surprising, in fact, that culture is not therefore a function of natural vegetation to a greater degree than actually obtains. That it is not, suggests the preponderant strength of purely cultural forces."

One of the objectives of the writer's Aleutian investigations was to determine the nature and cause of vegetational peculiarities on old village sites and refuse heaps. This particular study was part of a larger program of correlated anthropological and biological field work (Bank et al. 1950) sponsored by the University of Michigan. ${ }^{2}$ Studies in anthropology were conducted by the writer, Janet $F$. Bank, and Albert C. Spaulding of the University of Michigan; W. R. Hurt, University of South Dakota; and D. S. McClain, Trinity College, Connecticut. Botanical studies were made by the writer, L. H. Jordal, and H. A. Miller, University of Michigan. During the 1950 and 1951 seasons, T. C. Parks, University of Washington, undertook zoological studies on Adak, and archaeological work in 1951 was efficiently aided by volunteer assisttants K. K. Bay, Walter N. Dyakanoff, Jane E. Phillips, and Noel L. Wyatt.

In order to coordinate field studies ashore with observation from the air,

${ }^{2}$ Appreciation is expressed to the Office of Naval Research and the Michigan Memorial Phoenix Project for research funds which made these studies possible and to the U. S. Navy, Army, Air Force, Coast Guard, and the Alaska Native Service for cooperation generously given during our Alaskan investigations. I am also grateful to Professors H. H. Bartlett and Pierre Dansereau for help and advice. Plant specimens are in the herbarium of the University of Michigan and the U. S. National Herbarium. 
landings were made on more than 20 islands during eighteen months of 194849 and again during the summers of 1950 51. While ashore it was possible to visit a number of prehistoric villages and refuse mounds, some of which were hitherto unreported, and to study their vegetational and cultural characteristics by means of ecological transects across them as well as by archaeological excavation. Definitive reports on the cultural findings will be published later, and hence these data are treated only superficially in this paper.

\section{Aleutian Villages}

Every scientific observer in the Aleutians comes away with the realization that practically every island, no matter how smalt, has contained native villages. Each bay, inlet, cove and bight which affords protection from the worst storms was probably inhabited at one or more times during the period of Aleut occupation of the Aleutian Arc. Many narrow isthmuses along the coasts of even the rockiest islands also show village remains, and small kitchen middens or refuse piles representing temporary fish camps are found almost everywhere. The large number of Aleutian villages drew comment from early Russian explorers, many of whom estimated the population of the Archipelago to surpass 20,000 persons. Such an estimate may have been too high, for early attempts at census taking, when the population had already dwindled, placed the number of surviving Aleuts at only 1,900 (Petrof 1884: 33). Kroeber (1947: 135) gives the figure 16,000 for the estimated population at the time of Bering's visit in 1741. Since that date the Aleuts have almost entirely disappeared through mass slaughter by early Russians, introduced diseases, and starvation. Of the 90 to 150 or more villages which probably existed in 1741 , less than a dozen remain (Fig. 1). Instead of 16,000 or more Aleuts then, less than 1,200 are alive today, and half of these reside outside of their original homeland.

Prior to Bering's visit the appropriateness of a location for a village seems to have been a reasonably nearby source of fresh water, which in the Aleutians is nearly always at hand, and a fairly protected stretch of beach for landing the

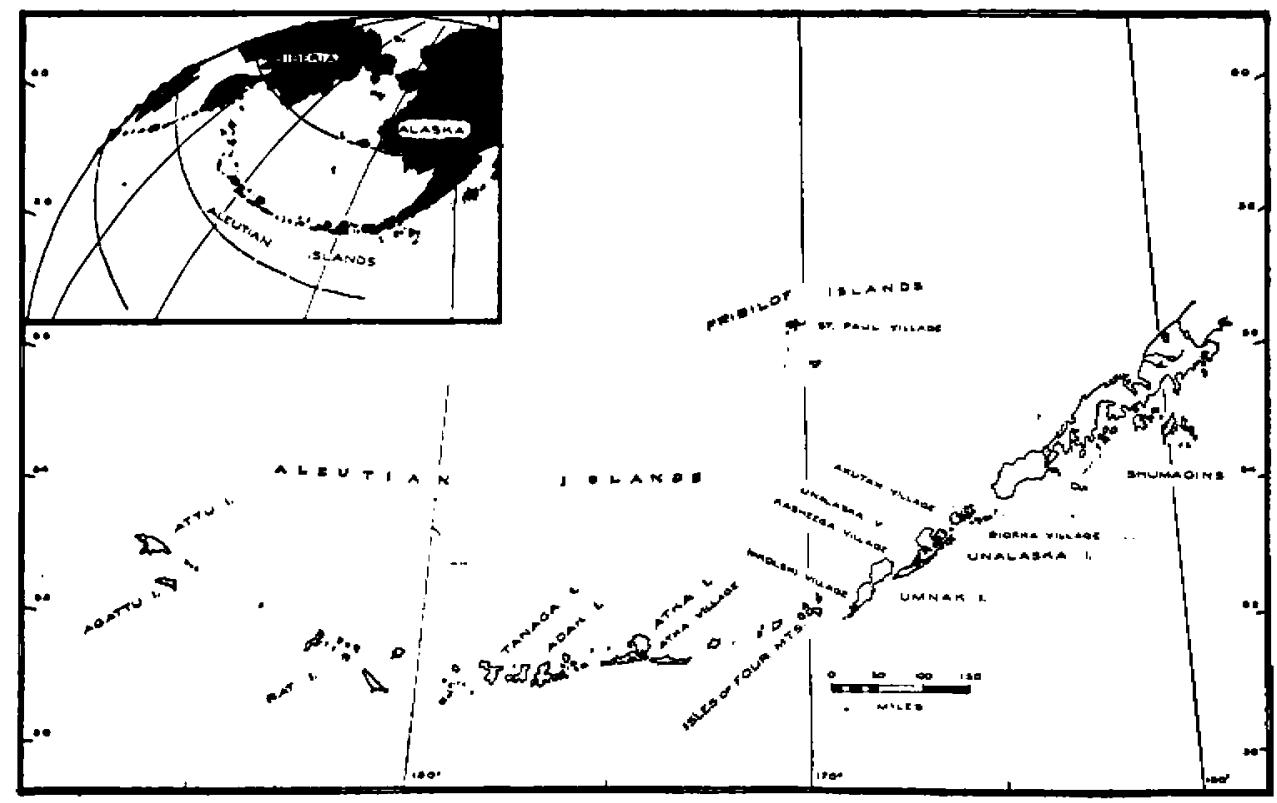

FIG. 1. The Aleutian Arc. Inhabited villages in the Aleutian Islands are shown. 
skin boats (bidarkas). However, the latter was actually a minor consideration, for the boats were extremely maneuverable and light. Escape from enemies was especially important to the Aleut. According to Russian accounts (Jochelson 1925: 23 and Petrof 1884: 146-151), Aleut villages during the early years of Russian discovery were mostly located on points of land and narrow isthmuses. Since the Aleuts frequently engaged in inter-island conflict, a good view in two directions and ready access to an escape route by water were of vital importance to them. Attack by a superior force might necessitate hurried transporting of all skin bidarkas across land to provide for the retreat of the entire village; hence many villages were located so that there would be ocean on two sides. The early Aleuts also made use of hills near their villages as lookout posts, in order to avoid surprise by enemies, but also to detect sea mammals which furnished much of their diet. After the Russians brought an end to local warfare, the villages were gradually moved to protected bays and river mouths (Fig. 2). The advantages of better fishing, protection from storms, and more room made the occupation of the more favorable sites highly desirable. Also, the Russians themselves frequently brought together the inhabitants of several villages at a single location for easier administrative control.

Old villages varied from a half acre to ten acres in extent and might consist of five, twenty, or even more than fifty underground dwellings (barabaras). Prior to Russian influence, the Aleuts built these barabaras with an entrance through the sod-covered roofs but later modified them, presumably under direction from the Russians, by placing the doorway in the sides. The earthen walls of the dwellings were frequently reinforced with driftwood, whale bones, and large slabs of stone. Over the driftwood and whale bone rafters, woven grass matting, dried grass and sod were usually laid. One or more families occupied such a dwelling; if more than one, portions of the inside were separated by grass mats. Larger communal barabaras were occasionally constructed, in which many families lived, but the Aleut use of kazims, i.e., large, separate council houses, has not been established.

The remains of Aleut dwellings are seen in section during archaeological excavation. Since abandonment they have caved in, but supporting rafters and soil strata peculiar to them mark their positions in the earth. A sectional view of one such collapsed barabara uncovered on Unalaska is shown (Fig. 3). Immediately below the old floor of the dwelling and to either side are usually found layers of sea urchin shell, fish bone, and intermingled bones of sea mammals, as well as cultural remains. Burials were sometimes made in the earthen walls and sealed up with stone and soil; these are occasionally apparent during archaeological excavation.

\section{Procedure}

Selection of sites for study depended largely upon convenience and accessibility, for transportation was available only as military needs provided. A number of village locations were obtained by interrogation of Aleuts; others were incidentally discovered in the course of botanical investigations. Time ashore at any one site was always conditioned by the weather and the necessity of conforming with military schedules.

Our field parties located more than 60 archaeological sites ranging from the Shumagin Islands in the east to Attu in the west. Sixteen of these, located on 10 islands, were given only surface study. Archaeological excavations were completed at sites on 4 of the islands. In order to avoid repetition, several of the more representative sites may serve as examples. Results from these are closely agreeable with others, except that the Nikolski mound (Umnak Island) was noticeably different and is discussed separately. The ancient village sites treated in this paper are Krugloi Point (Agattu), Campers Cove (Adak), Waterfall Site 

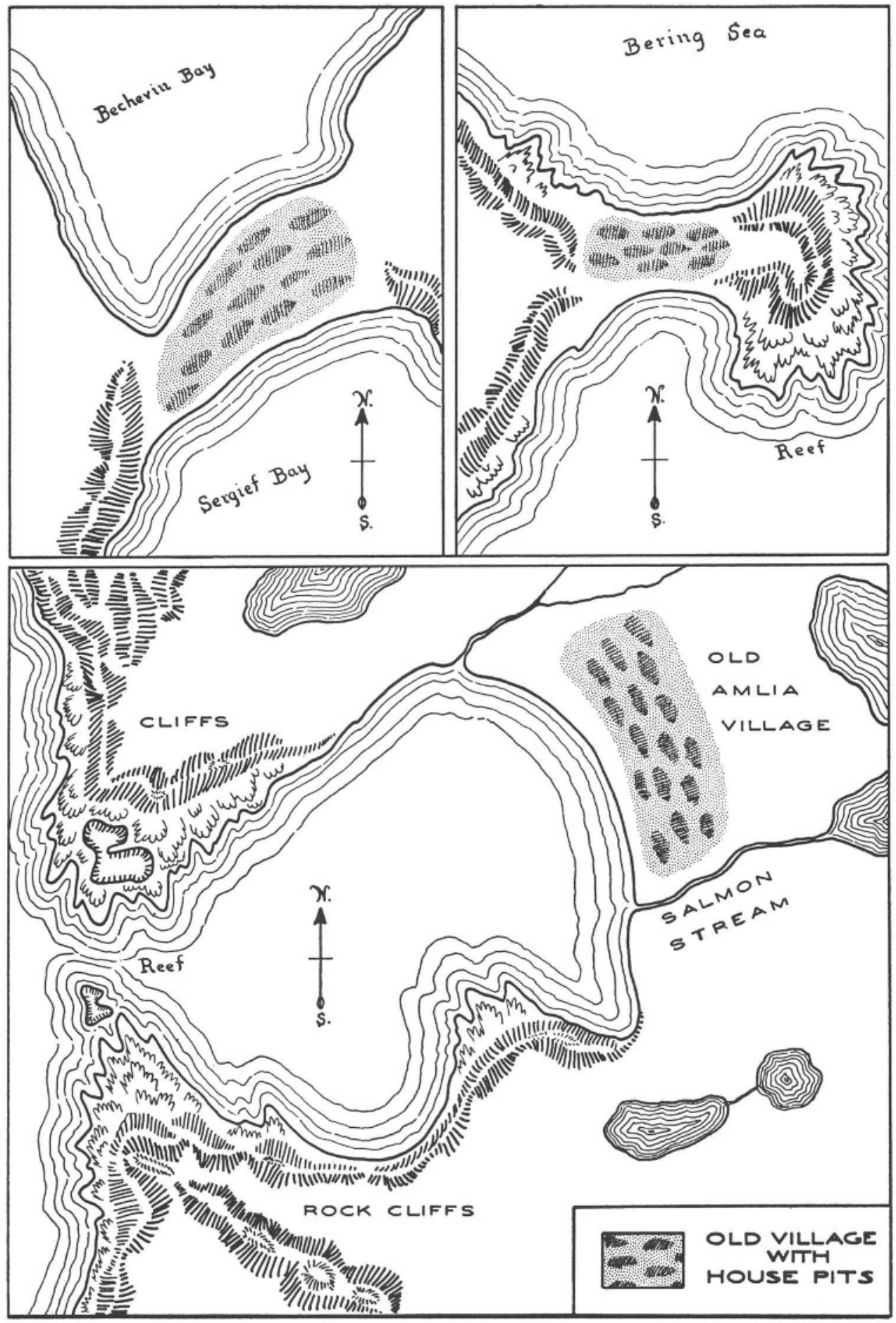

Fig. 2. Pre-Russian and post-Russian village sites in the Aleutians. Upper left: Sergief Bay, Atka Island; upper right: Bluefox Bay, Atka Island. Both are typical pre-Russian sites, which were located on isthmuses and points and offered an easy route of escape in case of hostile attack. Bottom: small cove on western tip of Amlia island, a sheltered village location preferred after 1741 . 
(Atka), Amaknak-D (Amaknak), Eider Point (Unalaska), and Nikolski (Umnak). The map in Figure 1 gives the locations of the islands.

Detailed measurements were not always feasible because of insufficient time ashore. However, study transects were used whenever possible, and numerical estimates of plants were supplemented by check counts, photographs, and plant collections. Distance was measured by pacing or steel tape. All transects were arbitrarily established with due regard to vegetational patterns and special features on the site. They varied in length but were 10 feet wide. Each extended into adjacent habitats, and, in addition, control strips on non-village areas were examined. Quadrats 10 feet square at various intervals provided data for counts. Several hundred soil samples were collected from dif- ferent sites and at varying depths, and these are being examined by specialists in microbiology. Tests of soil $\mathrm{pH}$ with the La Motte indicator set supplemented other observations.

\section{Plant Ecological Studies}

Beginning in the central Aleutians, the islands of Adak and Atka present old villages which were investigated. The Adak site, hitherto unstudied, lies in Campers Cove on the eastern side of the island facing Kagalaska Straits. It comprises an area approximately 200 feet by 150 feet with 35 evident barabara (house) pits. On Atka island, approximately two miles by dory along the coast southeast of the present village on Nazan Bay, another old site of comparable size was examined. Jochelson (1925: 30-45) reported doing some work at this location in 1910 , and

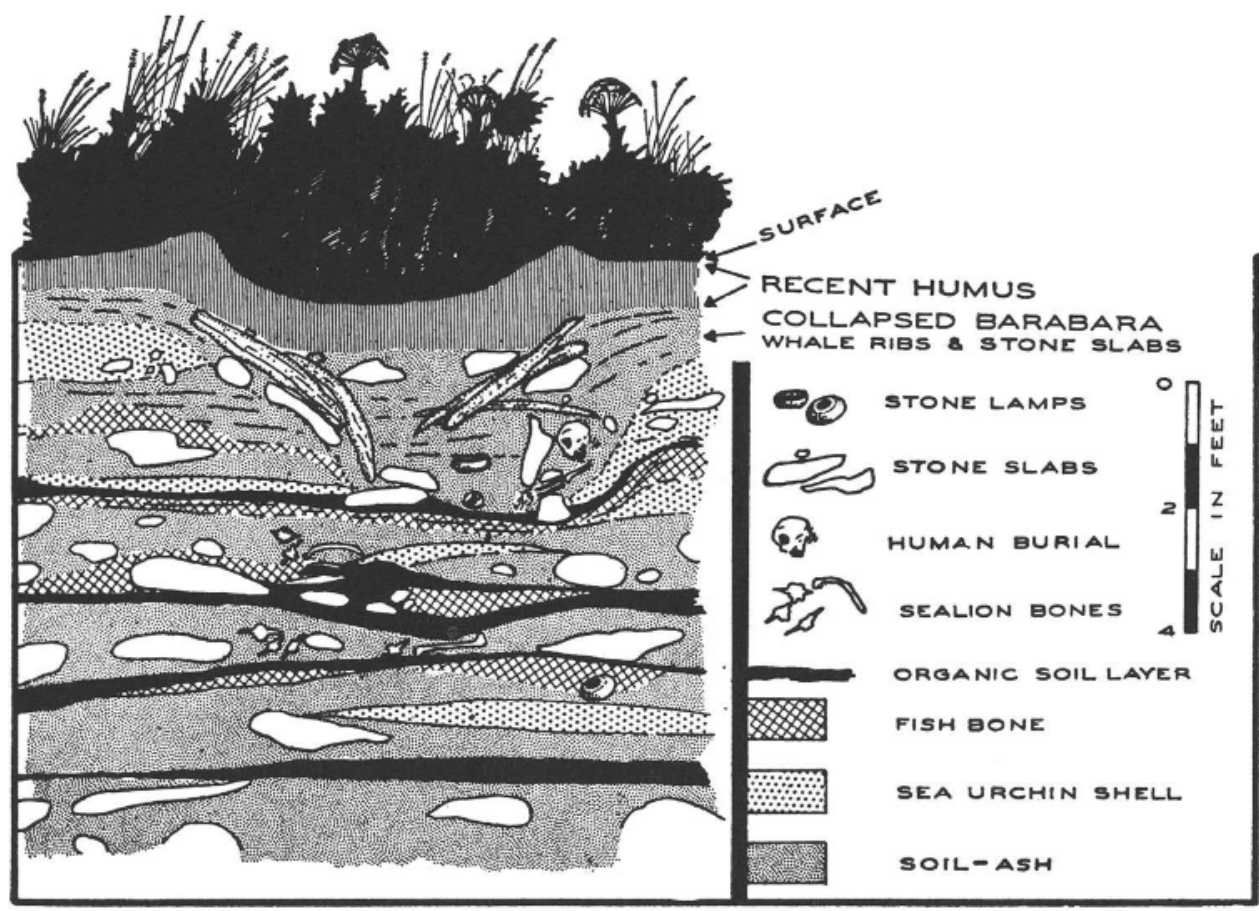

FIG. 3. Diagrammatic profile of an excavation at Eider Point, Unalaska Island. A house pit and subsurface archaeological deposits are shown. Whalebones probably supported the sod roof of the former barabara (underground dwelling of the Aleuts). Roots of surface vegetation, especially Heracleum, reached to the shell layers. Typical plants inhabiting former village sites are indicated and include: Heracleum, Elymus, Angelica, Conioselinum, Achillaea, Claytonia, Ligusticum, and Aconitum. 


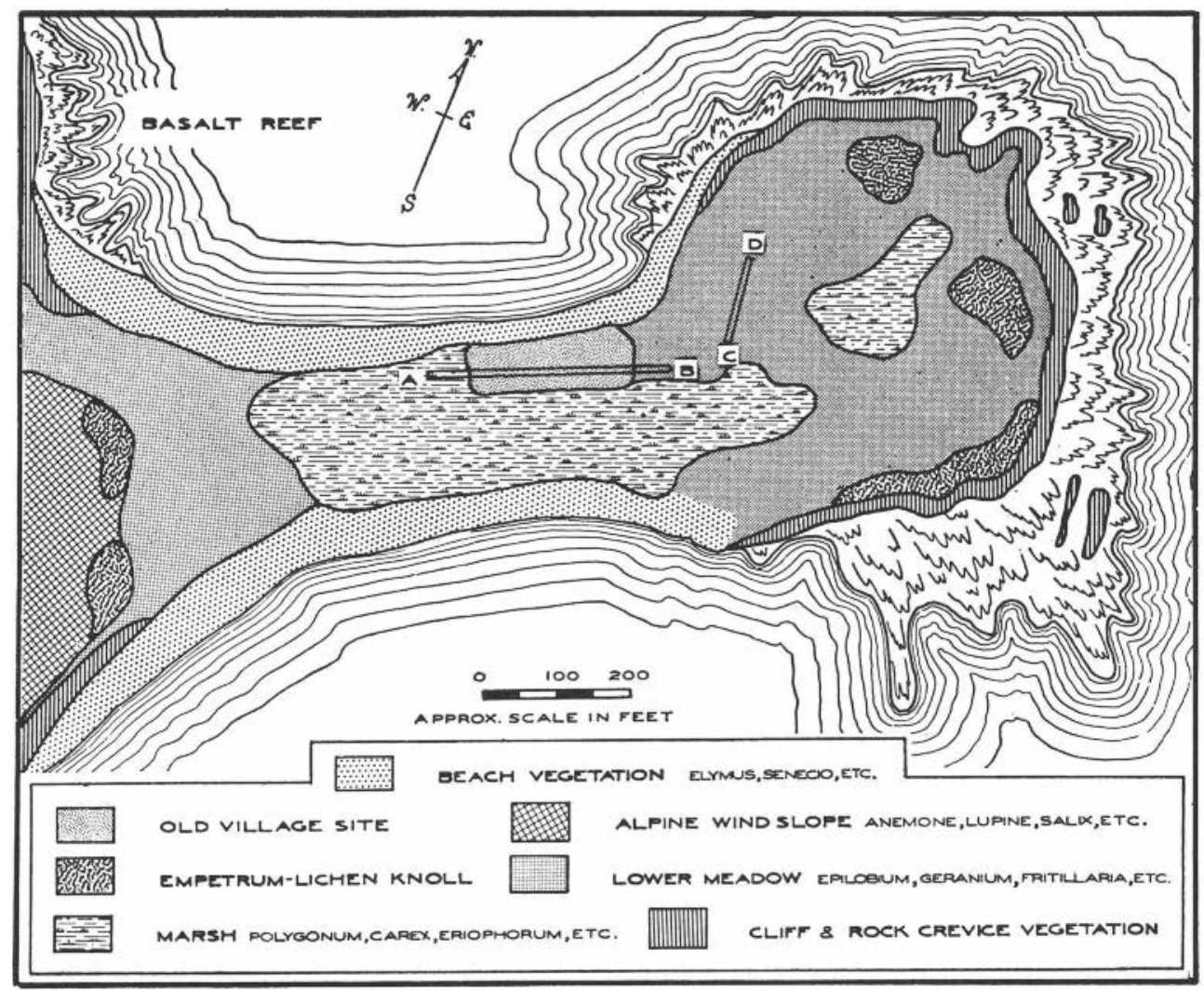

FIG. 4. Old village (waterfall site) and adjacent plant habitats at Nazan Bay, Atka Island. Locations of the study transect (A-B) and the control strip (C-D) are shown. Both are $10 \mathrm{ft}$. wide. Plants occurring on the transects are given in Table II and in Figure 10.

Hrdlička (1945: 219, 319), referring to it by its present name, the Waterfall Site, excavated here in 1936 and 1937. The writer investigated both sites in 1948 and 1949. At Atka, the study transect extended approximately east and west from a low marshy area, across the old village and thence up a gentle hill on the east (Fig. 4). At Adak, the transect also ran west to east from a lowland meadow, across the site to the beach. A control strip 10 feet wide and 30 feet long was situated entirely within the meadow at a distance of 30 yards from the village boundary. Both villages have been abandoned at least 100 years, according to information received from Aleut informants at Atka. The vegetational composition of these two sites is almost identical to what is found at other old villages at Attu, Tanaga, Amukta and Kagamil and is believed to be representative of all such sites which have not been disturbed recently.

In the eastern Aleutians, two large village mounds are situated at Eider Point on Unalaska Island (Unalaska Bay) and on the southwestern shore of Amaknak Island (Dutch Harbor). It was possible to study both mounds during the course of archaeological excavation. The Eider Point village measures $170 \times 280$ feet and was found to extend to an excavated depth of almost 30 feet! The point of land lies northwest and southeast. At Amaknak ${ }^{3}$ the mound is approximately

${ }^{3}$ Our site is the one Quimby (1946) refers to as midden-D. 


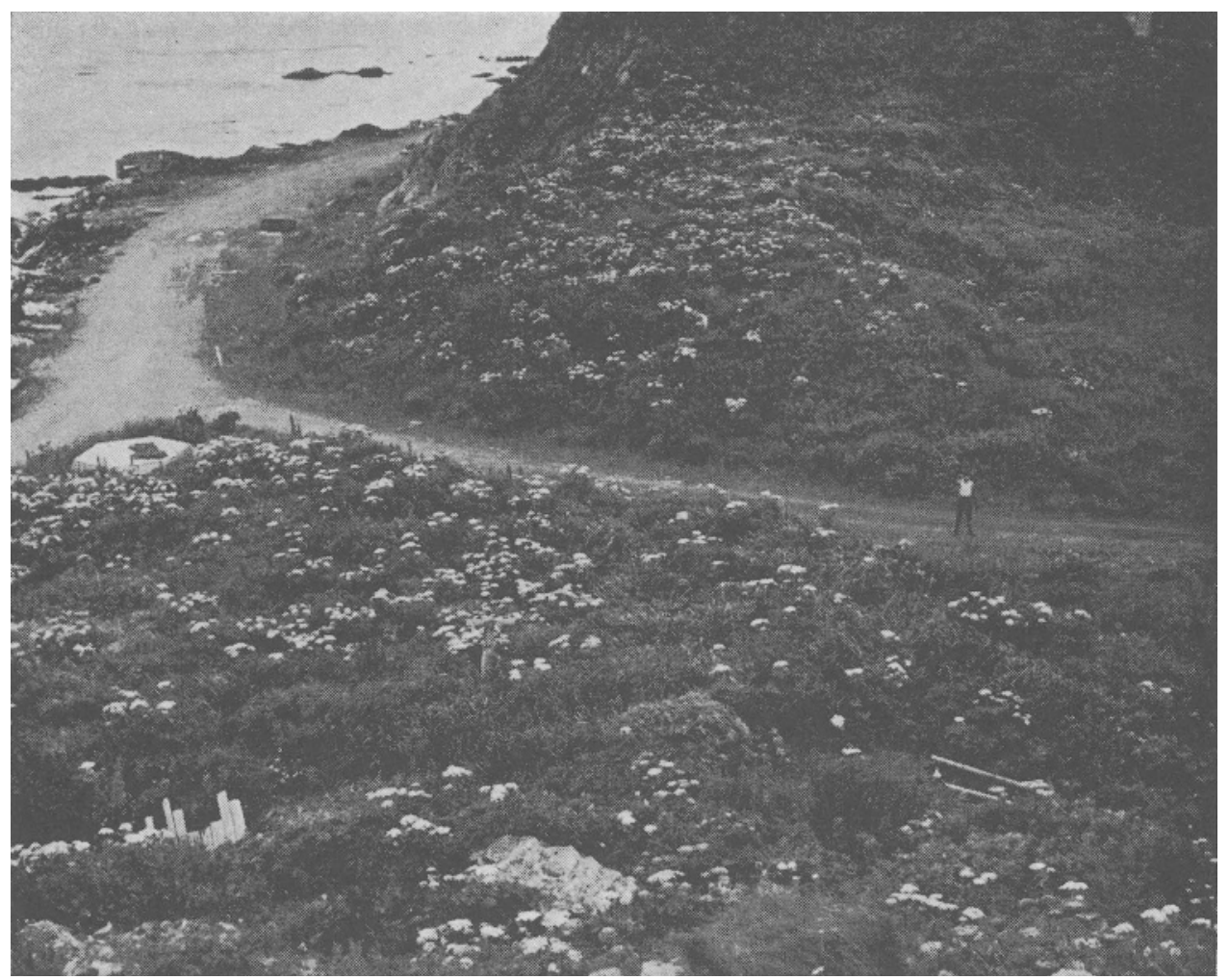

FIG. 5. Old village mound at Amaknak Island in Unalaska Bay. A military road constructed in 1942 bisects the mound. Typical old village vegetation can be seen; especially abundant are Heracleum lanatum (white umbels), Elymus arenarius mollis and Achillaea borealis. In some places, especially along the edge of the mound, Anaphalis margaritacea var. occidentalis and Epilobium angustifolium var. macrophyllum occur in dense stands. Wartime use of the mound introduced some plants. Three other archacological sites on Amaknak were destroyed by military construction, and presumably few of the artifacts were saved.

$130 \times 220$ feet, with long axis north and south. Cultural remains were recovered to a depth of 18 feet, below which there are layers of gravel and cobble. Both mounds are largely composed of alternating strata of sea urchin and clam shell, fish bone, and sea mammal bones. Both are said by Aleut residents at Unalaska to be "very old," and neither has been occupied as a village site for at least 150 years. At Amaknak the mound is bisected by a military road constructed during World War II (Figs. 5 and 7). The Eider Point site has likewise been modified by military operations. The uppermost 1 to 3 feet of soil and vegetation were removed in 1942 to clear the area for gun mounts.
However, since abandonment of the site by the military in 1945 , the vegetation has again grown up and, what is more, there is reproduced what was probably the original plant cover, i.e., species characteristic of all undisturbed old villages studied, with a few introduced additional species, such as Rumex fenestratus ${ }^{4}$ and Trifolium repens which do not normally occur on such sites. The vegetation on the Eider Point mound seems unusually lush, more so than on some other village sites which have not been as recently altered.

4 Nomenclature in this paper follows that of Hultén (1937 and 1941-1950). 
In the western Aleutians, H. A. Miller of our expedition made similar studies at an old village site (Krugloi Point) on Agattu. This village, exposed on a windy point of the extreme northeastern side of the island, is said by the Aleuts to have been abandoned for at least 100 years, probably much longer. Its surface configuration and vegetational pattern are similar to eastern Aleutian villages.

Partial results of these ecological studies are presented for Adak (Table I, Fig. 8), Atka (Table II, Fig. 10), Amaknak (Fig. 7), and Eider Point (Figs. 3, 6). Soil $\mathrm{pH}$ figures from 6 inch depths are shown in some cases in addition to indications of plant species occurring on the study strips.

It is evident from these data that soil $\mathrm{pH}$ increases as one approaches sites of former human habitation and that the difference in $\mathrm{pH}$ between village area and non-village area is substantial. There is also a definite, easily recognized vegetational pattern on villages which is not duplicated on adjacent habitats. It will be shown that this particular plant community is not found anywhere in the Islands except upon abandoned village sites and consists of a mixture of plant species normally associated with three natural habitats, namely: the grass hummock zone near beaches, wet ravines, and the grass meadow habitat of the lowland valleys. I believe that the village vegetation comprises an association-segregate, i.e., an association that has differentiated out of mixed associations of the lowland habitats, in this case not because of climatic influence but as a result of longpersisting edaphic changes brought about

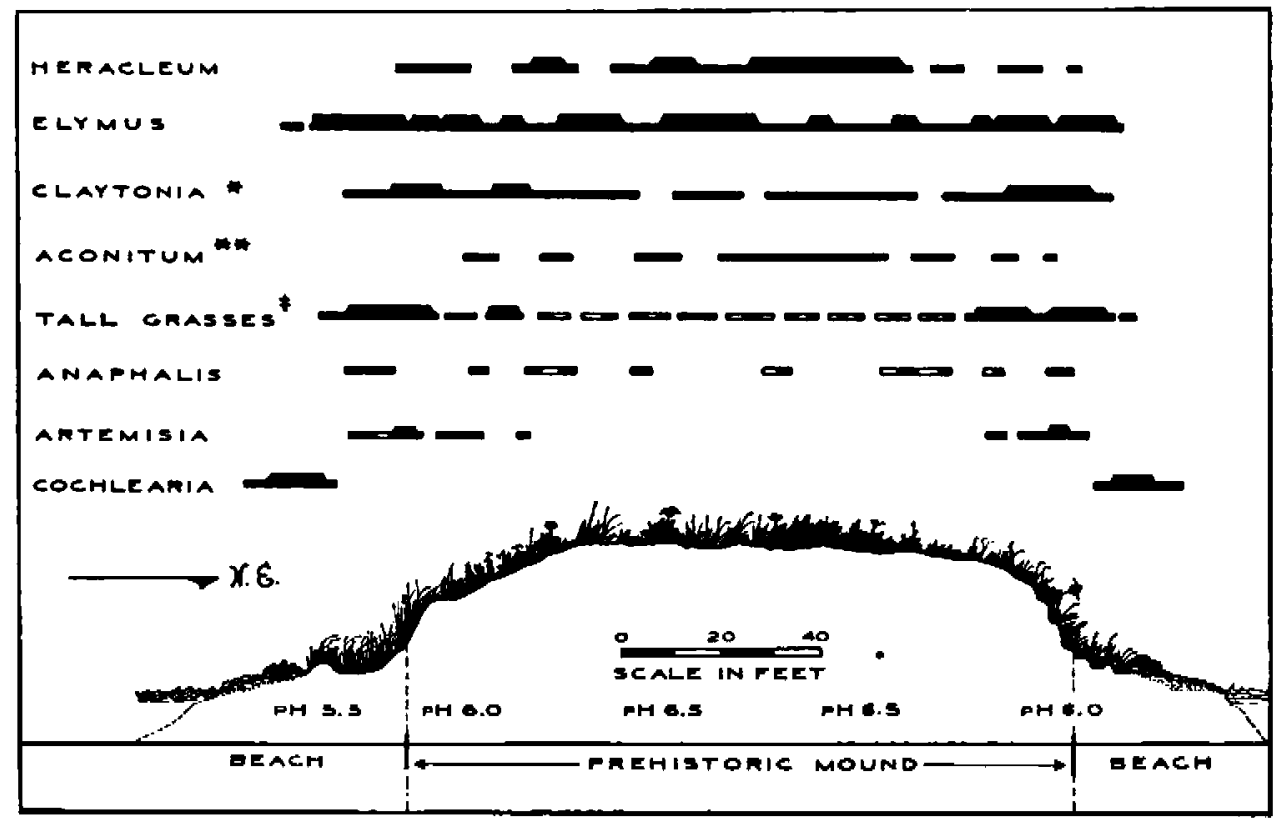

FIG. 6. Diagrammatic profile of a prehistoric mound at Eider Point, Unalaska Island. Distribution of the most abundant plants is indicated by horizontal bars; heavier bars represent greater abundance; broken bars represent scattered occurrence. * Conioselinum, Ligusticum and Angelica also occur, distributed about the same as Claytonia. ** Achillaea occurs, distributed much like Aconitum. †Tall grasses include Calamagrostis langsdorffi ( $C$. canadensis var. langsdorffi), Deschampsia beringensis, Festuca rubra, Phleum alpinum var. americanum. The Artemisia is $A$. unalaschensis. Soil pH values from a 6 inch depth are given at the bottom. Figure 3 is a profile of a single house pit on this same mound and indicates subsurface deposits. 
TABLE I. Plant species and $p H$ values from $10 \times 10 \mathrm{ft}$. quadrats of a transect across an old village site at Campers Cove, Adak Island, Aleutians

\begin{tabular}{|c|c|c|c|}
\hline $\begin{array}{l}\text { Location of } \\
\text { quadrats }\end{array}$ & Habitat type & $\begin{array}{c}\text { Soil pH } \\
\text { at } 6 \text { inch } \\
\text { depth }\end{array}$ & Plant species most abundant \\
\hline $\begin{array}{l}50 \text { yards west } \\
\text { of site }\end{array}$ & $\begin{array}{l}\text { Moist, grassy } \\
\text { meadow with } \\
\text { gentle easterly } \\
\text { slope }\end{array}$ & 5.5 & $\begin{array}{l}\text { Agrostis exarata, Festuca rubra, Trisetum spicatum, etc. } \\
\text { Athyrium flix-femina, Dryopteris sp. } \\
\text { Platanthera dilatata, Orchis aristata } \\
\text { Epilobium angustifolium var. macrophyllum } \\
\text { Cornus suecica, Lupinus nootkatensis (clumps) } \\
\text { Anemone narcissiflora var. villosissima }\end{array}$ \\
\hline $\begin{array}{l}20 \text { yards west } \\
\text { of site }\end{array}$ & $\begin{array}{l}\text { Lush meadow } \\
\text { with gentle } \\
\text { easterly slope; } \\
\text { well-drained }\end{array}$ & 6.0 & $\begin{array}{l}\text { Lupinus nootkatensis (scattered clumps) } \\
\text { Calamagrostis langsdorffi, Festuca rubra } \\
\text { Deschampsia beringensis, other grasses } \\
\text { Athyrium filix-femina, Dryopteris sp. } \\
\text { Anemone narcissiflora var. villosissima } \\
\text { Geranium erianthum, Pedicularis chamissonis } \\
\text { Cornus suecica, Arnica unalaschcensis } \\
\text { Fritillaria camschatcensis, Orchis aristata }\end{array}$ \\
\hline $\begin{array}{l}\text { Western edge } \\
\text { of site }\end{array}$ & $\begin{array}{l}\text { Gentle west- } \\
\text { erly slope; } \\
\text { well-drained }\end{array}$ & 6.0 & $\begin{array}{l}\text { Heracleum lanatum, Elymus arenarius mollis } \\
\text { Calamagrostis langsdorffi, Deschampsia beringensis } \\
\text { Fritillaria camschatcensis, Geranium erianthum } \\
\text { Athyrium filix-femina, Aconitum maximum }\end{array}$ \\
\hline Center of site & $\begin{array}{l}\text { Hilly and } \\
\text { fairly well- } \\
\text { drained }\end{array}$ & 7.5 & $\begin{array}{l}\text { Elymus arenarius mollis, Heracleum lanatum } \\
\text { Athyrium filix-femina (abundant) } \\
\text { Aconitum maximum, Achillaea borealis } \\
\text { Conioselinum gmelini, Angelica lucida } \\
\text { Ligusticum hultenii, Claytonia sibirica }\end{array}$ \\
\hline $\begin{array}{l}\text { Eastern edge } \\
\text { of site }\end{array}$ & $\begin{array}{l}\text { Sloping toward } \\
\text { beach on east; } \\
\text { wet }\end{array}$ & 7.5 & $\begin{array}{l}\text { All plants that are found at the center of the site; } \\
\text { in addition: Ranunculus occidentalis var. insularis } \\
\text { Calamagrostis, Deschampsia, Festuca } \\
\text { Phleum alpinum var. americanum }\end{array}$ \\
\hline $\begin{array}{l}20 \text { yards east } \\
\text { of site bor- } \\
\text { dering on } \\
\text { cobble } \\
\text { beach }\end{array}$ & $\begin{array}{l}\text { Gentle easterly } \\
\text { slope to beach; } \\
\text { boulders and } \\
\text { driftwood } \\
\text { present }\end{array}$ & 6.5 & $\begin{array}{l}\text { Tall grasses (as above); Elymus especially abundant } \\
\text { Senecio pseudo-arnica, Claytonia sibirica } \\
\text { Honckenya peploides, Cerastium caespitosum } \\
\text { Mertensia maritima, Lathyrus maritimus } \\
\text { Cochlearia officinalis, Potentilla villosa }\end{array}$ \\
\hline
\end{tabular}

by man's occupation. The reasons for this view will be presented shortly.

The characteristic plants of this association-segregate are tall members of the Umbelliferae (Heracleum lanatum, Conioselinum gmelini, Angelica lucida, and Ligusticum hultenii) together with the grass Elymus arenarius mollis, and Claytonia sibirica, Achillaea borealis, and Aconitum maximum, the poisonous monkshood (Fig. 8). Aconitum is found in greater abundance on sites in the western Aleutians. Companion plants, i.e., those without any pronounced affinity for this association over another, include ferns (usually Athyrium filix-femina but sometimes Dryopteris sp.), tall grasses such as Calamagrostis langsdorffi, Festuca rubra, Deschampsia beringensis, etc., and occasionally in the east, Anaphalis margaritacea var. occidentalis. On Kodiak Island, much the same vegetation occurs on old village areas, with the addition of stinging nettle (Urtica) and, frequently, elderberry (Sambucus). Abundance of characteristic and companion plants are roughly expressed as follows: constantly present (80-100\%), Heracleum, Elymus, Conioselinum, Achillaea, and in the west, Aconitum; mostly present (60-80\%), Claytonia, Angelica, Ligusticum, Calamagrostis, Deschampsia, and in the east, Aconitum; often present (40-60\%), ferns and in the east Anaphalis; seldom present 
(20-40\%), Epilobium, Ranunculus, Cornus, and Trientalis; rarely present (1$20 \%$ ) are recently introduced plants such as clover and invaders from wet, boggy habitats.

One of the village areas, the Nikolski mound, has a vegetataion which has been greatly modified by man and animals, in this case, sheep. The mound is an imposing structure about 25 feet high, situated just south of the present village of Nikolski on the western end of Umnak Island (Fig. 9). The village is inhabited by 56 Aleuts, the school teacher and her husband. Two of the native houses are situated atop the prehistoric mound.
About a half-mile farther south is the white-owned sheep ranch, from which the stock frequently roam over the surrounding territory.

A study strip was established which extended from a stream on the north, over the mound to a shallow lake on the south. The transect was thus about 400 feet long. Vegetation occurring along this strip included : at the stream margin, Epilobium anagallidifolium, Polygonum viviparum, Juncus balticus, Carex spp., Rumex acetosella, $R$. fenestratus, Caltha palustris, Mimulus guttatus, and Equisetum arvense; north edge of mound where the ground rises sharply, Ranunculus occidentalis

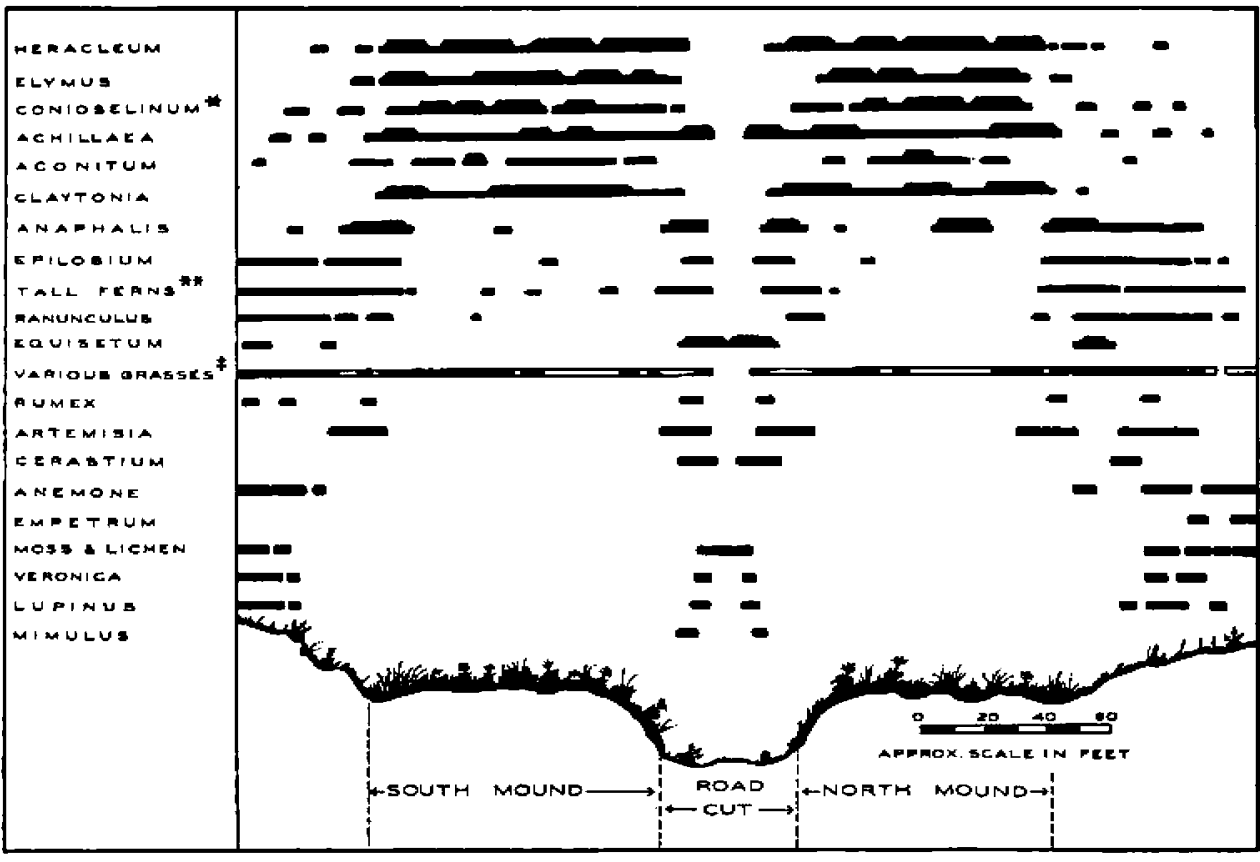

FIG. 7. Diagrammatic profile of prehistoric mound at Amaknak Island, same as shown in Figure 5. Distribution of the most abundant plants is indicated by horizontal bars; heavier bars indicate greater abundance; broken bars represent scattered occurrence. * Ligusticum hultenii and Angelica lucida also occur predominately on the mound with about the same pattern as shown for Conioselinum. ** Tall ferns are Athyrium Filix-femina, although some Dryopteris also occurs. ¥Various grasses include those given in the legend below Figure 6 , but they are not as abundant here. Other plant species occurring on the transect are: Heracleum lanatum, Elymus arenarius mollis, Conioselinum gmelini, Achillaea borealis, Aconitum maximum, Claytonia sibirica, Anaphalis margaritacea var. occidentalis, Epilobium angustifolium, var. macrophyllum, E. latifolium, E. anagallidifolium, Ranunculus occidentalis var. nelsonii, Equisetum arvense, Rumex fenestratus, $R$. acetosella, Artemisia unalaschensis, Cerastium caespitosum, Anemone narcissiflora var. villosissima, Empetrum nigrum, Veronica spp. (unidentified), Lupinus nootkatensis, and Mimulus guttatus. 
var. nelsonii, Mimulus, Galium aparine, Epilobium angustifolium var. macrophyllum, Equisetum, and sparse short grasses; atop the mound, Trifolium repens, short grasses such as Poa arctica zilliamsii, Mimulus, Achillaea borealis, Elymus arenarius mollis, and scattered plants or clumps of Aconitum maximum and Claytonia sibirica; south of mound near shallow lake, Trifolium repens, Mimulus, Sphagnum spp., Caltha, Rumex acetosella, and short grasses with some sedges and reeds.

At least two plants have been introduced, e.g., Trifolium and probably $G a$ lium, and the sheep, as well as the constant trampling of the mound by human beings, have greatly influenced both the amount and the kind of plant cover. Mimulus, Sphagnum and numerous mosses have invaded, but some of the characteristic old village vegetation is still present, although scattered, e.g., Achillaea, Claytonia, Elymus, and Aconitum.

At Adak and Atka, individual house pits were stripped of their surface vegetation so that a close census could be made of the plants occurring within them. The figures, together with data from quadrats, gave results which indicated relative abundance of certain plants showing special sensitivity to topographic features on the site. Data for Elymus, Heracleum, Aconitum, Polygonum, and Conioselinum are graphically presented (Fig. 10). Each dot represents a plant within a strip ten feet wide. Barabara pits are discernible from patterns made by plant species favoring them.

Whereas Aconitum seems to show no particuar preference for house pits over any other portion of the village, Heracleum is definitely more abundant within the pits. However, at Atka several barabara

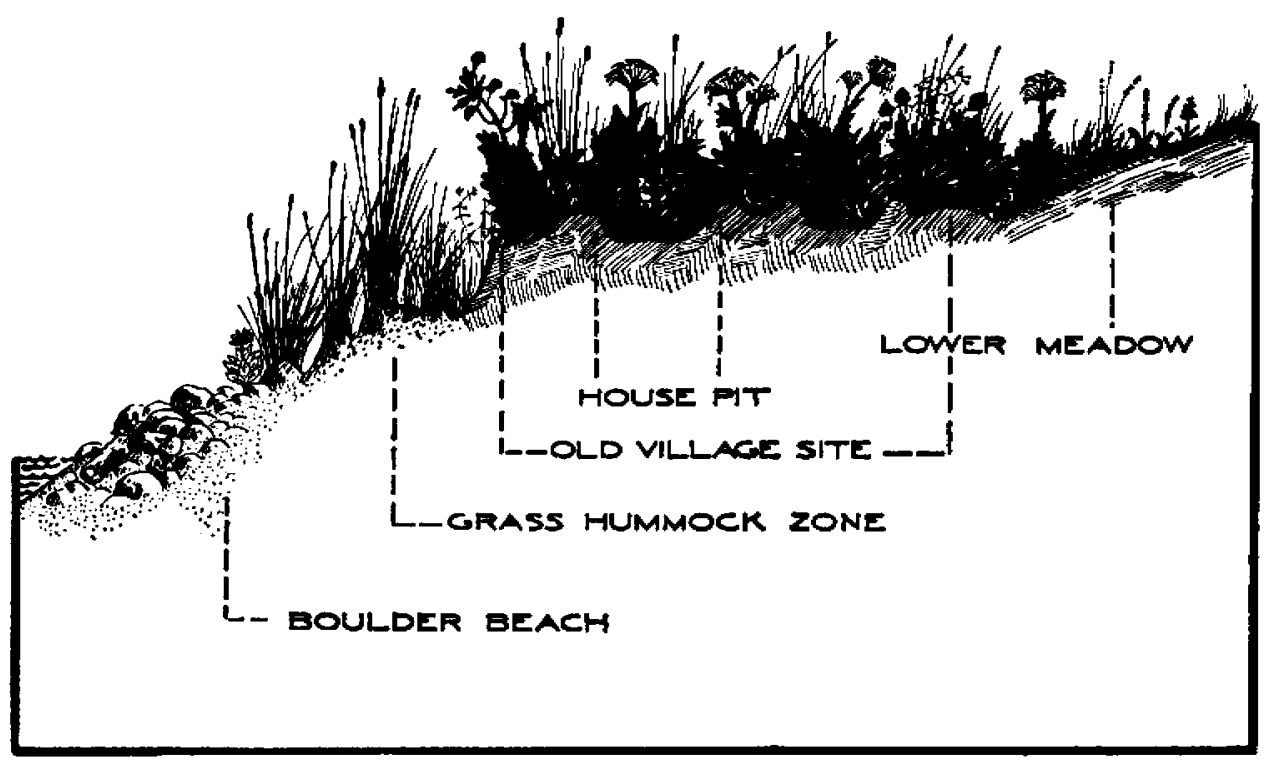

FIG. 8. Diagramatic section of a typical small village site, based on an actual site on Adak, showing barabara pits, lush vegetation usually occurring on old villages, and the characteristically narrow ecotones between the village plant community and adjacent communities. The most abundant plants on the village area are the same as those listed below Figure 3 . Occurring in the meadow complex are: Polygonum viviparum var. macounii, Agrostis exarata, Trisetum spicatum, Poa macrocalyx, Festuca rubra aucta, Pedicularis chamissonis, Arnica unalaschcensis, Geranium crianthum, Ranunculus occidentalis var. insularis, Barbaraea orthoceras, Epilobium behringianum and others. Making up the beach and hummock complexes are: Senecio pseudoarnica, Lathyrus maritimus, Elymus arenarius mollis (also Deschampsia, Calamagrostis, etc.), Claytonia sibirica, Mertensia maritima and others. 
TABLE II. Plant species and $p H$ values from $10 \times 10 \mathrm{ft}$. quadrats of a transect across an old village site at Nazan Bay, Atka Island, Aleutians

\begin{tabular}{|c|c|c|c|}
\hline $\begin{array}{l}\text { Location of } \\
\text { quadrats }\end{array}$ & Habitat type & $\begin{array}{c}\text { Soil } \mathrm{pH} \\
\text { at } 6 \text { inch } \\
\text { depth }\end{array}$ & Plant species most abundant \\
\hline $\begin{array}{l}30 \text { yards } \\
\text { west of } \\
\text { site }\end{array}$ & $\begin{array}{l}\text { Low, wet } \\
\text { marshy area }\end{array}$ & 4.5 & $\begin{array}{l}\text { Carex macrochaeta, C. hindsii, C. anthoxanthea } \\
\text { Eriophorum chamissonis, Juncus balticus } \\
\text { Polygonum viviparum, Plantago macrocarpa } \\
\text { Hippuris vulgaris, Rumex acetosella, Equisetum arvense } \\
\text { Scirpus caespitosus, Luzula parviflora, Poa komarowii var. } \\
\text { vivipara } \\
\text { Iris setosa (1 specimen), Conioselinum gmelini (1 specimen) }\end{array}$ \\
\hline $\begin{array}{l}\text { Western } \\
\text { edge of } \\
\text { site }\end{array}$ & $\begin{array}{l}\text { Sharply ris- } \\
\text { ing ground; } \\
\text { wet from } \\
\text { seepage of } \\
\text { water from } \\
\text { site }\end{array}$ & 5.5 & $\begin{array}{l}\text { Elymus arenarius mollis, Deschampsia beringensis, Poa sp. } \\
\text { Heracleum lanatum, Claytonia sibirica, Achillaea borealis } \\
\text { Conioselinum gmelini, Ligusticum hultenii, Streptopus amplexi- } \\
\text { folius } \\
\text { Athyrium flix-femina, Dryopteris sp. } \\
\text { Cerastium caespitosum, C. fischerianum, Aconitum maximum } \\
\text { Ranunculus occidentalis var. insularis }\end{array}$ \\
\hline $\begin{array}{l}\text { Center of } \\
\text { site }\end{array}$ & $\begin{array}{l}\text { Moist; un- } \\
\text { even surface } \\
\text { due to old } \\
\text { house pits; } \\
\text { about } 6 \mathrm{ft} \text {. } \\
\text { higher than } \\
\text { marsh to } \\
\text { west }\end{array}$ & 7.5 & $\begin{array}{l}\text { Heracleum lanatum, Elymus arenarius mollis, Conioselinum } \\
\text { gmelini } \\
\text { Angelica lucida, Claytonia sibirica, Athyrium filix-femina } \\
\text { Ligusticum hultenii, Achillaea borealis, Aconitum ma rimum } \\
\text { Deschampsia beringensis, Calamagrostis langsdorffi, Festuca } \\
\text { rubra (these grasses scattered over the site) } \\
\text { Ranunculus occidentalis var. insularis (scattered) }\end{array}$ \\
\hline $\begin{array}{l}\text { Eastern } \\
\text { edge of } \\
\text { site }\end{array}$ & $\begin{array}{l}\text { Rising ab- } \\
\text { ruptly to- } \\
\text { ward east; } \\
\text { well-drained }\end{array}$ & 7.0 & $\begin{array}{l}\text { All plants that are found at the center of the site; Elymus is } \\
\text { especially abundant } \\
\text { Epilobium angustifolium var. macrophyllum } \\
\text { Fritillaria camschatcensis, Lycopodium clavatum (scattered) }\end{array}$ \\
\hline $\begin{array}{l}30 \text { yards } \\
\text { east of } \\
\text { site }\end{array}$ & $\begin{array}{l}\text { Fairly steep } \\
\text { southerly } \\
\text { slope; well- } \\
\text { drained }\end{array}$ & 5.0 & $\begin{array}{l}\text { Poa macrocalyx (?), Carex macrochaeta, Trisetum spicatum } \\
\text { Polygonum viviparum, Pedicularis chamissonis, Arnica unala- } \\
\text { schcensis } \\
\text { Erigeron peregrinus, Cornus suecica, Lycopodium spp. }\end{array}$ \\
\hline $\begin{array}{l}50 \text { yards } \\
\text { east of } \\
\text { site }\end{array}$ & $\begin{array}{l}\text { Dry knoll, } \\
\text { very well- } \\
\text { drained at all } \\
\text { times }\end{array}$ & 4.5 & $\begin{array}{l}\text { Lycopodium clavatum and others, Cladonia spp., Empetrum } \\
\text { nigrum } \\
\text { Cornus suecica, Trientalis europaea arctica, Linnaea borealis } \\
\text { Veronica stelleri, Phyllodoce aleutica, Poa spp. (scattered) }\end{array}$ \\
\hline
\end{tabular}

pits falling outside of the transect did not show this pattern. These are probably the pits which were excavated in 1936 and 1937 by Hrdlička, and perhaps this would account for the difference. It is tentatively suggested that Heracleum grows better within the house pits because of more favorable $\mathrm{pH}$ conditions there. Moisture accumulation, i.e., constantly damp soil but no standing water within the pits, is greater than elsewhere on the site, which also may account for the denser growth of cow parsnip in them.

Elymus seems to grow more densely along the periphery of the old village and, too, along the slightly raised margins of the house pits. Perhaps slightly more acid conditions resulting from leaching of the soil accounts for this. Tests as conducted by our group, however, were not sufficiently sensitive to measure minor differences in $\mathrm{pH}$. Although the plotted data indicate dense growths of Elymus bordering the house pits they do not show equally dense stands which occur elsewhere on the site. These latter stands, however, are on slightly raised hummocks of about the same height as the pit margins. Quick drainage may be a determining factor of the habitat.

Polygonum viviparum was plotted to show the distribution of a typical plant 
occurring frequently in habitats adjacent to the old village. Intolerance to the old village site is marked. However, this is not true of some other widely occurring plants such as the grasses Deschampsia and Calamagrostis, as well as Cornus suecica, Ranunculus spp., Trientalis europaea arctica, and some species of Epilobium, which seem to grow equally well, although in scattered condition, both on and off old village areas on some of the islands. At Nikolski, this is also true of the introduced clovers (Trifolium repens) and Rumex acetosella.

On the whole, the midden soils are loosely packed and very porous, due to the archaeological remains, shells, and so forth, contained in them and also because of the high percentage of pumiceous, volcanic ash generally found in Aleutian soils. The soil underlying house pits is less porous than elsewhere on the sites and drainage is poorer. Porosity of the soils is, of course, an important factor regulating the amount of certain chemicals available to plants from the soil. On the other hand, soil saturation with water is high in the Aleutians due to almost constant precipitation, and this, combined with fairly low soil temperatures, causes a low rate of organic decomposition, which in turn makes possible the slow release of certain chemicals from organic matter, over an unusually long period of time. Although no measurements were made to ascertain it, midden soils undoubtedly contain much calcium and probably considerable phosphorus and nitrate in comparison to other Aleutian soils, due to the abundant subsurface fish bone, shell, and other fertilizing deposits. The amount of leaching, which might quickly remove the nitrate, has not been determined, but it is probable that the percentage of nitrate

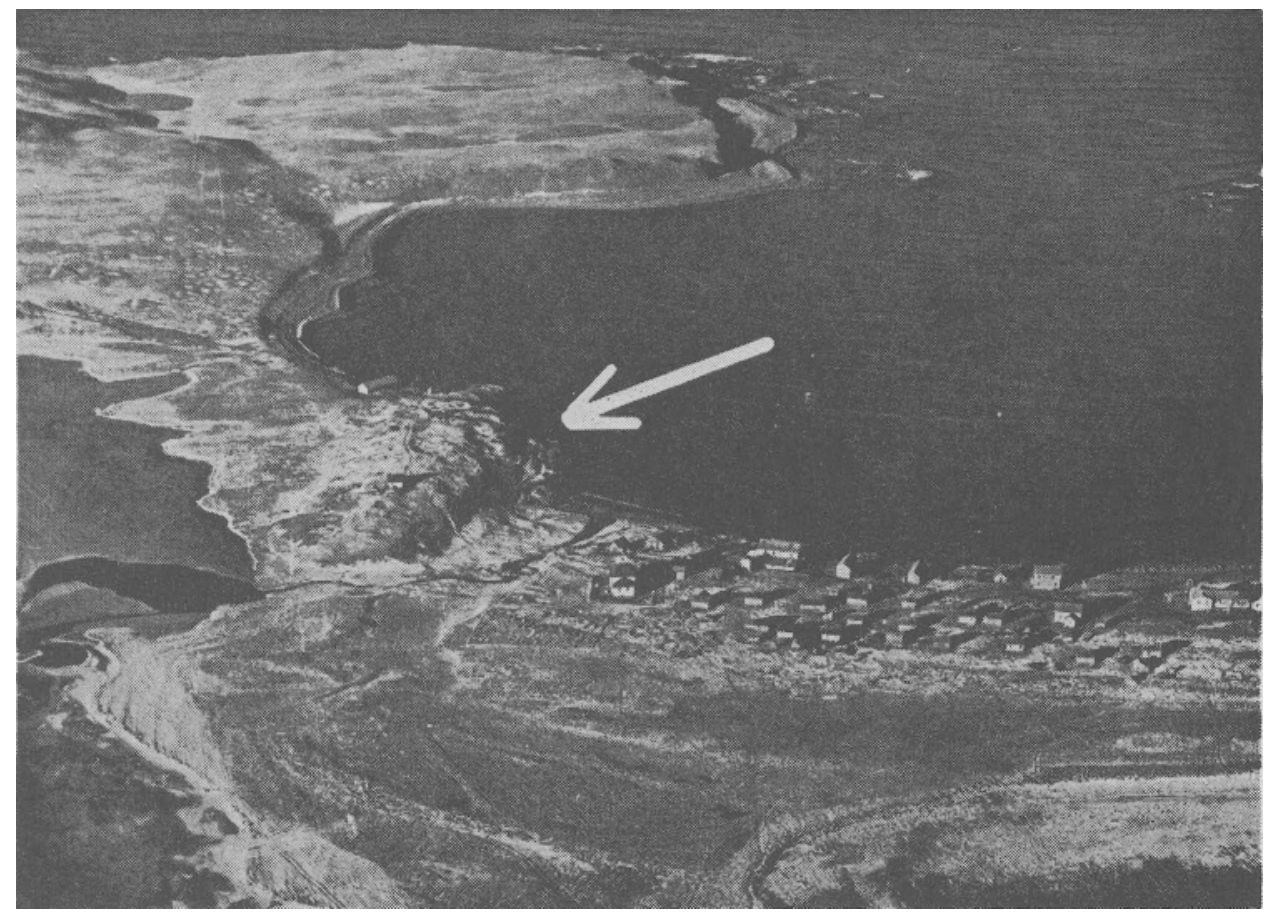

FIG. 9. Nikolski village, Umnak Island, from the air. Large prehistoric mound is indicated by arrow. Vegetation in this part of the island has been affected by sheep from the ranch shown in the extreme upper left corner. Depressions in the hillside which can be seen just above and to the left of the mound are probably barabara pits and represent another ancient site. (Official U. S. Navy Photograph.) 

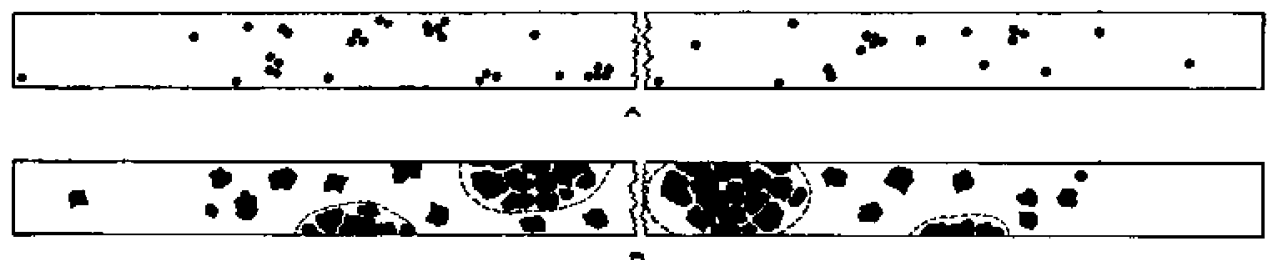

F

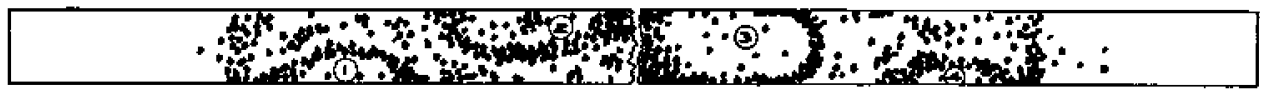

$<$
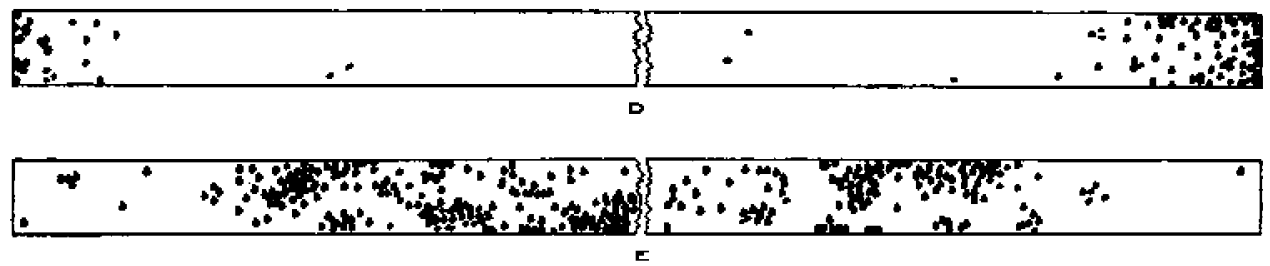

FIG. 10. Diagram showing distribution of certain plant species on the study strip across the former village (waterfall site, Fig. 4, Table II), Nazan Bay, Atka Island. The strip is 10 feet wide and about 330 feet long, but for convenience the middle segment is left out. Plant distribution on this portion of the transect was similar to what is shown within the village boundaries. Each dot represents a plant; thus the diagrams present the distribution of: A) Aconitum maximum; B) Heracleum lanatum, shows partiality to house pits; C) Elymus arenarius mollis, shows partiality to pit margins; D) Polygonum viviparum, shows intolerance to village area; E) Conioselinum gmelini. Barabara (house) pits, 1-4, are indicated by the patterns of plants favoring them.

in midden soils is greater over a long period of time than it is in non-midden soils in the Aleutians. The availability of the chemicals calcium, phosphorus, and nitrate determines the abundance of certain characteristic plants on old villages, probably more than any other factor. Thus, these, but not all of the plants on old village sites, compose a neutrophilous, possibly a nitrophilous plant community. Among the plants which are most abundant on these sites, Aconitum, members of the Umbelliferae, and Urtica (on Kodiak) would seem to be fairly reliable indicators of the increased presence of one or all of the chemicals calcium, phosphorus, and nitrate.

In order to complete a description of the vegetational peculiarities of old villages in the Aleutians, it is necessary to consider briefly the typical plant communities of non-village areas and the uses which the former Aleuts made of local plants. The latter subject has special significance in an explanation of village vegetational patterns. Aleutian plant habitats are treated in detail elsewhere and will not be dealth with exhaustively here. The interested reader may wish to refer to Hultén's excellent work (1937) and my own recent paper (1951).

\section{Plant Habitats Adjacent to Old VILLAGES}

Except that all villages were located near the sea, adjacent plant habitats vary considerably. The Atka site is bordered by a cobble beach on the north; a grassy meadow slope terminated by an Empetrum knoll on the east; a low, wet, grass marsh on the south; and a standing water marsh and seepage slope on the west (Fig. 4). Our site at Campers Cove, Adak, is bordered by a sandy beach, lowland meadow, seasonal mudflat, and lowland stream valley, whereas the Eider Point site is bor- 
dered on two sides by a cobble beach and reefs, on the third side by a steep, grassy meadow slope and terrace rock cliffs, and the point of land itself is terminated in a long, jagged basalt reef.

Aleutian beaches have been found to be primarily cobble and boulder, deeply wavecut, with extensive off-shore reefs and occasional patches, especially in the bays and inlets, of grey to black sand. Potentilla, Poa, and lichens inhabit the earth deposits in the crevices of shore rocks, and the cobble and sand beaches possess scattered growths of scurvy weed (Cochlearia officinalis), ragwort (Senecio pseudoarnica), beach pea (Lathyrus maritimus), and a number of grasses. Slightly back from the beach and occupying the marginal ridges and irregularly surfaced hummock zone will be found an association of wild-rye (Elymus arenarius mollis), spring beauty (Claytonia sibirica), Senecio, and numerous grasses, especially Calamagrostis langsdorffi, Deschampsia beringensis, Phleum alpinum var. americanum, and Festuca rubra. Beyond the hummocks, there usually exist several terraces or rock walls or sometimes steep, grass meadow slopes whose vegetation includes, in addition to Calamagrostis and other grasses, geranium (Geranium erianthum), lousewort (Pedicularis chamissonis), Epilobium spp., and numerous smaller plants, e.g., Trientalis europaea arctica, Geum calthifolium, etc. Here also occur scattered plants of Heracleum, Conioselinum, Aconitum, and Anaphalis. Dry knols with thick carpets of tundra berry (Empetrum nigrum), lichens ( $\mathrm{Cla}$ donia and others), and mosses, as well as blueberries (Vaccinium uliginosum var. alpinum) and bunchberry (Cornus suecica) usually terminate these hilltops. Stream valleys are frequently choked with lush growths of fern and grasses as well as such plants as the showy orchid (Orchis aristata), white orchid (Platanthera hyperborea), other platantheras, cucumber plant (Streptopus amplexifolius), yarrow (Achillaea borealis), and not infrequently Anaphalis, Epilobium, Artemisia, An- gelica, and Ligusticum, with some Heracleum. Still higher, where the winds continually blow and greatly restrict plant growth, there occur thin carpets of $E m$ petrum, lichens, Ericaceae and heath companions such as anemone and lupine, as well as scattered prostrate willows and a few grasses such as Calamagrostis purpurascens. No naturally occurring trees grow in the Aleutians although on Unalaska and Unimak there are scattered thickets of shrubby alder.

Characteristic of highland terraces and exposed points of land overlooking the sea are mounds which are steep-sided and conical, or rounded, and often 6 feet or more in height. In topography they may resemble middens, but excavation reveals them to lack human remains. These are bird-mounds (Fogletuer of Norwegian coasts); they have been formed through centuries from vegetation growing in the excrement of seabirds. Their vegetation has little in common with village mounds and human refuse heaps but is predominately made up of Carex macrochaeta, Festuca spp., Poa spp., Trisetum spicatum, the lichen Sphaerophorus globosus, Lycopodium spp., Sphagnum spp., and other mosses. A knowledge of this may save archaeologists a few hours of needless digging and the disappointment of finding only a large boulder at the bottom of an otherwise important-looking mound.

It is apparent from remains of old villages and from what we know of Aleut life at the time of Russian discovery that the island people were truly maritime and seldom ventured into the higher interiors of their islands. Only one village was located any distance from the sea, and it was distant only verticaly from the shore. It was observed on Agattu from the air. Consisting of a ring of small barabara pits in a circle about one much larger pit (possibly a kazim?), this village was situated atop a very high plateau with steep rock cliffs on three sides reaching to the sea below. The fourth side was a steep, heath-covered (?) slope decending toward the interior of the island. The 
inhabitants must have had most difficult access to the sea but an almost impenetrable bastion of defense. It is not impossible that the village was once at sea level and the land has risen. Inasmuch as the Aleutian islands have undergone considerable uplifting in fairly recent times (U. S. G. S. 1947), it is conceivable that the oldest villages may not be near the sea at all but must be sought on the higher terraces, which for the most part have not been explored archaeologically.

\section{Aleut Plant Uses}

The plant lore of the Aleuts was once quite extensive according to information obtained from living natives and from perishable detritus in archaeological sites. The main body of ethnobotanical data will be published later, but briefly, the Islanders used more than sixty local plants for food, drink, medicines, and in the manufacture of such articles as grass mats, baskets, boat frames, etc. Beach pea (Lathyrus maritimus), and such grasses as Elymus, Bromus, and Calamagrostis, as well as some Carex, were used in weaving. Cow parsnip (Heracleum lanatum) and other of the Umbelliferae (Conioselinum gmelini, Ligusticum hultenii, Angelica lucida), as well as spring beauty (Claytonia sibirica), fireweed (Epilobium angustifolium var. macrophyllum) and many of the sea weeds (e.g., Ulva and Fucus) were extensively used by the Aleut for food. Roots of the lupine ( $\mathrm{Lu}$ pinus nootkatensis), black lily or riceroot (Fritillaria camtschatcensis), and the white orchid (Platanthera, several species) were used in various ways to supplement the fish diet. Leaves, stems, and roots were usually eaten raw and often were added to fish, berries, and water to make an uncooked fish "soup." Such plants as ragwort (Senecio pseudo-arnica), the common yarrow (Achillaea borealis), and the marsh-growing Matricaria matricarioides were known to be strong medicines.

From driftwood on the beaches, the
Aleut fashioned boat frames, supports for the semisubterreanean houses, and lances. Taxus, Picea, and Chamaecyparis were the principal woods used. Cedar (Chamaecyparis), which drifted from the American Mainland, was carved into masks and shamanistic objects. The roots of monkshood (Aconitum maximum) were ground by some Aleut groups to extract the poison, which was then applied to harpoon points for whale hunting. As is true of this practice, much of the use of local plants has disappeared among the surviving Aleut.

It is apparent that the early Aleut never had to wander very far inland for useful plants. The majority of species which were used are readily accessible in the lowland meadows, stream valleys, marshes, and along the sea shore. Berries are plentiful in Empetrum mats which are never very far from village locations. It is striking that the characteristic plants today occurring on long abandoned village sites were all at one time used by the Aleut. Heracleum, Conioselinum, Ligusticum, Angelica, and Claytonia were used for food. Achillaea, Heracleum, and Ligusticum were mainstay medicines, and Aconitum was used as a whale and fish poison. Elymus was the primary source of weaving material.

It has been shown that Elymus and Claytonia frequent the hummocks and old terraces behind the shore line. Claytonia, but not Elymus, is also sometimes found in a loose association of Conioselinum, Ligusticum, Heracleum, and Angelica in lowland stream valleys. Achillaea may be found on the steeper banks that are drained and also with scattered growths of Heracleum, Conioselinum, and Aconitum in lowland meadows. The Aleuts used all of these plants; today they are found closely associated on abandoned village sites, but are otherwise from several differing habitats. This suggests a direct human influence on the vegetation of old villages, and this influence may be the primary historical factor 
which determined the particular combination of plants on these sites.

\section{Use of Vegetation in Archaeological RECONNAISSANCE}

This ecological study of old villages gives a method of locating such sites not only by surface exploration but also by aerial reconnaissance. During several flights across the entire Archipelago at low altitudes, it was possible to locate and map a large number of hitherto unreported villages. This information will be invaluable to future archaeological work in the Aleutians and will be published in the near future.

When viewed from the air, old Aleut villages present a unique appearance, being seen as dark green areas against the lighter greens and yellows of the surrounding vegetation. This is explained by the greater abundance of tall darkcolored plants such as Aconitum and Heracleum on the sites as compared with the lower-growing plants which prevail on non-village areas. From the standpoint of lushness and greeness of vegetation, many valleys and stream margins show the same dark green coloration, although not as sharply defined and hence usually not mistaken for archaeological sites. The lateness of season to which Heracleum and Aconitum retain their dark greeness gives to the margins of old villages an especially sharp delimitation in the early fall when the surrounding meadows and bogs have already taken on the yelloworange coloration of winter. A strikingly distinctive feature of most village sites is the occurrence of depressed circular barabara (house) pits. These are likely to be choked with a heavy plant growth (as indicated in Figs. 3, 10), as well as being sunken, so that they are easily discerned even from high altitudes (Fig. 11).

There are already enough data at hand to determine not only the exact locations of old villages from the air but also,

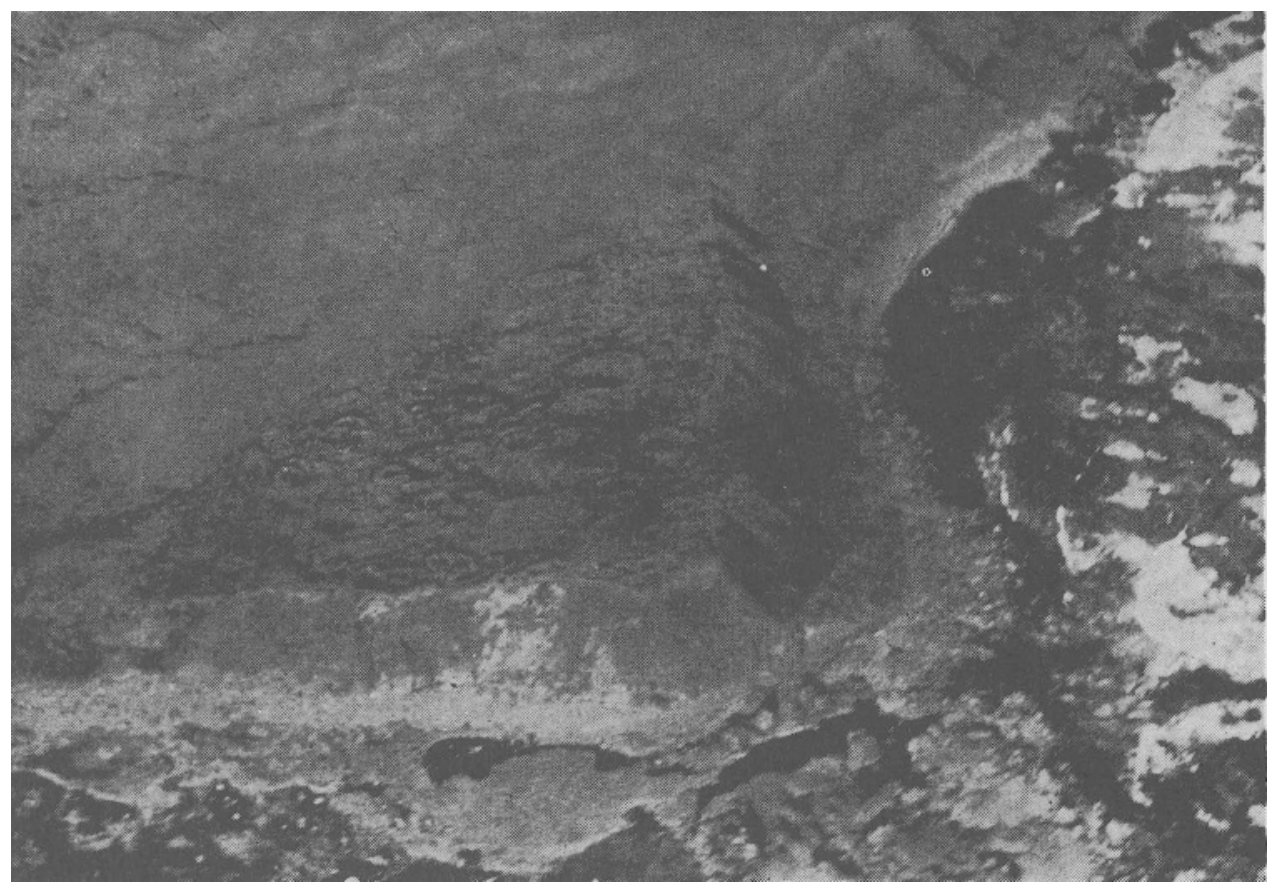

Frg. 11. Prehistoric Aleut village on Attu Island as seen from the air in September, 1949. Approximately 90 barabara pits can be counted, including several larger depressions which may have been community dwellings or possibly kazims. 
roughly, their approximate human populations. In this latter respect, it is usually sufficient merely to pick out the surface areas of old sites by noting the sharply defined color patterns and counting the easily discerned barabara pits. There is every indication that a close evaluation of the factors influencing plant growth on and off such areas in the Aleutians will bring forth a usable scale for giving rough determination of the age of old villages by the vegetation occurring on them. The lushness of the house-pit vegetation is quite certainly to be related to the richness of deposits of fish bones and other fertilizing materials in the barabaras. This richness is undoubtedly related in turn to the age since abandonment of the sites.

\section{Summary and Conclusions}

There seems to be a definite correlation shown on former Aleutian village sites between plant growth and soil $\mathrm{pH}$ and these in turn, are influenced by elevation, drainage, and subsurface archaeological remains of fertilizer value, such as fish and mammal bones. Through the interaction of the above factors and others which are unknown, a definite, easily discernible, plant association occurs on old villages that is not duplicated elsewhere. Although the same plant species occur separately and to some extent associated in localities removed from human habitation, such as lowland stream valleys, there is never the same degree of association between, e.g., Elymus and Heracleum, as on village sites. In addition, the density of growth and lushness are usually less on non-village areas. The increased availability of certain nutrients, notably calcium, phosphorus, and possibly nitrates, in the midden soils is probably the main ecological factor determining these vegetational differences.

Aside from the factors of $\mathrm{pH}$, drainage, elevation, and sub-surface deposits as reasons for the characteristic plant association on old villages, it is suggested that past Aleut plant economy may have been a factor. Every characteristic plant species occurring on the village areas was widely used by the Aleut as a source of food, medicine, poison or weaving material. Utilization was probably centered at the individual villages where undoubtedly the waste parts, especially the seeds, accumulated in abundance, establishing a ruderal vegetation which persists on the abandoned sites today.

The association-segregate, which I call the particular plant grouping on old villages, is evidentally made up of two, possibly more, separate plant communities, which, however, are not always distinguishable on every old village site. $\mathrm{Her}$ acleum and several other plants occur frequently as a single community within house pits, whereas Elymus and other grasses, sometimes with Achillaea, dominate pit margins, hummocks and the peripheries of villages, forming a somewhat distinct community. The details of this distinction are not sufficiently clear at present to allow a more complete discussion, but the many sensitive ecological factors which operate to determine these and other differing microhabitats on the ancient villages are certainly worthy of further consideration.

Identification of old villages from the air is easy, especially during the early months of fall and spring when the vegetational differences stand out with spectacular clearness. By aerial reconnaissance, which in the Aleutians is the most practical, the archaeologist can locate and map sites on the islands ranging across the entire Arc, including the Alaska Peninsula. It is possible not only to ascertain size and position of the sites from the air but also in most cases to count the numbers of barabara pits. This may even be done from photographs.

The problem now is not where to find villages for Aleutian archaeology but rather one of careful reconnaissance by air to locate and map the largest, most easily reached, and most productive-looking sites. Such a survey would not entail a great amount of time or money, provided military aircraft regularly flying 
this route could be utilized. It should produce valuable data upon which could be based a plan for intensive, careful archaeology in the Aleutians during the next few decades.

It is possible that additional work on this problem will reveal a correlation between surface vegetation and age since abandonment of the villages. Such a correlation would seem to exist since the recently disturbed sites, such as Eider Point, present a denser vegetation than do villages abandoned longer, although it may prove too tenuous a relationship to be of practical value to the archaeologist. It may be a relatively temporary cultivation effect, resulting from improved aeration and the bringing of fertilizer nearer to the surface. The depth of leaching out of fertilizer constituents since abandonment might provide the reason for a correlation of vegetation differences with antiquity, if such differences can actually be discerned and measured.

\section{REFERENCES}

Bank, T. P., II. 1951. Botanical and ethnobotanical studies in the Aleutian Islands, $I$. Aleutian vegetation and Aleut culture. Pap. Mich. Acad. Sci., Arts \& Lett. 37: 13-30. [1952.]

Bank, T. P., II, A. C. Spaulding, H. A. Miller, and Janet F. Bank. 1950. The
University of Michigan expedition to the Aleutian Islands, 1948-49. A report to the Office of Naval Research ("restricted"). 220 pp., Botanical Gardens, Ann Arbor.

Dall, W. H. 1877. On succession in the shellheaps of the Aleutian Islands. Pub. of the U. S. Geogr. \& Geol. Survey of the Rocky Mt. Region 1: 41-91.

Daniel, G. E. 1950. A hundred years of archaeology. 1st ed. Duckworth, London.

Hrdlixka, Ales. 1937. Man and plants in Alaska. Science 86: 559-560.

- 1945. The Aleutian and Commander Islands and their inhabitants. Wistar Inst. Anat. \& Biol., Philadelphia.

Hultén, E. 1937. Flora of the Aleutian Islands. Bokförlags Aktiebolaget Thule, Stockholm.

- 1941-1950. Flora of Alaska and Yukon. Lunds Univ. Arsskrift N. F. Ard 2, Bd. 37-46.

Jochelson, W. 1925. Archaeological investigations in the Aleutian Islands. Carnegie Inst., Washington, D. C.

Kroeber, A. L. 1947. Cultural and natural areas of native North America. Univ. of Calif. Press, Berkeley.

Petrof, I. 1884. Report on the population, industries, and resources of Alaska. U. S. Census Office, Washington, D. C.

Quimby, G. I. 1946. Toggle harpoon heads from the Aleutian Islands. Fieldiana. Anthropology 36 (2): 15-23.

U. S. Geological Survey. 1947. Alaskan volcano investigations. Report No. 2, 105 pp. U. S. Govt. Print. Office, Washington, D. C.

Zeiner, H. M. 1945. A botanical survey of Angel Mounds site. Amer. Jour. Bot. 33: 83-90. 